\title{
THE DESCRIPTION OF VIOLENCE AMONG SCHOOL-AGE CHILDREN IN YOGYAKARTA
}

\author{
Nina Dwi Lestari¹, Oktalisa Puspita Arum² \\ 1,2Program Studi Imu Keperawatan, Fakultas Kedokteran dan Ilmu Kesehatan, Universitas \\ Muhammadiyah Yogyakarta, Bantul \\ e-mail: ninadwilestari240708@gmail.com
}

\begin{abstract}
Introduction: The occurrence of violence to students increases every year. It came from their parents, environment, and the students. The violence types were physical, verbal or emotional, sexual, and economy. There were several consequences from the violence such as disruption of the child psychic, seriously injured, or trauma. Method: This research used quantitative descriptive with cross sectional design. The population in this research was 220 elementary students in Yogyakarta. The sample of this research was 130 samples that was taken used random sampling technique. The criteria of sample were the students who allowed to participate the research with their parents or parents and never diagnose or have no mental illness beforehand. The instrument in this research was a questionnaire about violence overview that was developed by the researcher and had undertaken the validity and reliability tests. The data analysis used descriptive analysis. Result: Mostly, the violence to the students was dominated by female $(51.5 \%)$ and students in the low economic background (62.3\%). There was an occurrence of violence $(56.9 \%)$ and verbal violence $(68.9 \%)$ as the common violence. The largest violence location commonly happened at school $(93.2 \%)$. Conclusion: The violence prevalence was quite large to students and commonly happened at school. Further research about the factors that influenced the occurrence of violence was needed.
\end{abstract}

Keywords: Physical Violence, Sexual Violence, Verbal Abuse, Type of Violence, School-Age Children

\section{PENDAHULUAN}

$\begin{array}{lrr}\text { Kekerasan } & \text { anak } & \text { adalah } \\ \text { perbuatan } & \text { disengaja } & \text { yang }\end{array}$ mendatangkan kerugian atau bahaya terhadap anak secara fisik maupun emosional (Hurairah 2012). Menurut Hillis, et.al (2017) kekerasan pada anak termasuk dalam pelanggaran hak asasi manusia dan termasuk masalah sosial yang dapat berpotensi menghancurkan dan membahayakan anak dan berdampak pada negara.

Lebih dari 30\% anak di Amerika Latin mengalami kejadian kekerasan seperti kekerasan fisik dan seksual (Wirtz, et al., 2016). Angka kekerasan pada anak pada tahun 2011 adalah sebanyak 61 kasus, tahun 2012 terdapat 487 kasus, tahun 2013 terdapat 508 kasus dan di tahun 2014 terdapat 456 kasus (Erlinda, 2014). Berdasarkan data tersebut dapat disimpulkan bahwa kekerasan yang terjadi di Indonesia mengalami peningkatan setiap tahun. Kekerasan yang terjadi tersebut memiliki beberapa jenis.

Menurut Peraturan Menteri Negara Pemberdayaan Perempuan dan Perlindungan Anak Republik Indonesia Nomor 2 Tahun 2011 tentang Pedoman Penanganan Anak Korban Kekerasan, tindakan kekerasan dibagi menjadi 5 jenis, yaitu kekerasan fisik, kekerasan verbal atau emosional, kekerasan seksual, tindakan pengabaian dan penelantaran serta kekerasan ekonomi. Penelitian Latifah (2012), membuktikan bahwa $74 \%$ anak pernah mendapatkan tindak bullying fisik dan sekitar $87 \%$ anak pernah mengalami bullying verbal. Menurut Kementerian Kesehatan Republik 
Indonesia (2014) menunjukkan sekitar 9\% anak pernah menjadi korban dari perlakuan tindak senonoh. Pada tahun 2013 sebanyak $22,7 \%$ anak pernah mengalami pencabulan atau persetubuhan secara paksa yang dilakukan oleh orang lain (Kemenkes RI, 2014).

Berbagai jenis kekerasan tersebut terjadi disebabkan oleh beberapa faktor. Penelitian Suradi (2013) menunjukkan bahwa beberapa faktor yang berkontribusi terhadap terjadinya kekerasan meliputi orangtua, lingkungan di sekitar tempat tinggal anak dan faktor dari anak itu sendiri. Menurut Hurairah (2012), orang tua yang membesarkan anak dengan penganiayaan akan berdampak pada perkembangan anak terutama dalam meniru perilaku kekerasan yang didapatkannya. Suradi (2013) menjelaskan bahwa faktor lingkungan salah satunya lingkungan keluarga seperti status ekonomi keluarga juga dapat menjadi faktor resiko terjadinya kekerasan. Kondisi ekonomi khususnya kemiskinan berpengaruh pada timbulnya kekerasan secara ekonomi karena anak yang hidup dalam latar belakang perkonomian yang kurang mampu, anak akan dipaksa untuk ikut bekerja supaya mendapatkan tambahan pendapatan keluarga. Faktor dari individu anak seperti usia juga berkontribusi terhadap timbulnya kekerasan. Rohman (2016) menjelaskan bahwa kejadian kekerasan pada anak usia sekolah lebih banyak terjadi pada tingkatan kelas lebih tinggi yaitu kelas 4 s.d 6 . Semakin tinggi tingkatan kelas, semakin berisiko menimbulkan kekerasan karena fakor senioritas. Pada tingkatan ini anak lebih condong membentuk kelompok kecil yang dapat menyebabkan ketidakpercayaan antar teman sehingga memicu terjadinya tindak kekerasan. Selain usia, jenis kelamin pun dihubungkan dengan kejadian kekerasan. Anak laki-laki cenderung melakukan tindakan kekerasan secara langsung atau fisik sedangkan perempuan lebih condong ke arah kekerasan verbal (Silvia, Pereira, Mendonca, Nunes, dan Oliveira (2013).

Kekerasan yang terjadi pada usia sekolah jika tidak ditangani akan menimbulkan masalah yang serius di kemudian hari. Seseorang yang pada masa anak-anak sering melakukan tindak kekerasan, saat dewasa akan berubah menjadi seorang kriminal. Jika seseorang dari kecil sudah mendapatkan perlakuan kasar, didiskriminasi oleh sosial ataupun sudah ditelantarkan oleh orang tua, akan berdampak juga pada saat dewasa. Korban kekerasan pada anak-anak dapat menimbulkan sikap yang tertutup, tidak percaya diri, mempunyai harga diri rendah bahkan bisa menjadi anti sosial di kemudian hari (Zwierzynska, Wolke, \& Lereya, 2013; Morcillo, et al., 2015; Beattie, 2015).

Hasil studi pendahuluan pada 2 sekolah dasar di Yogyakarta, menggunakan teknik wawancara dengan 10 siswa di setiap sekolah tersebut, diperoleh hasil bahwa sekitar 8 dari 10 siswa mengalami tindak kekerasan. Jenis kekerasan yang sering terjadi pada kedua sekolah tersebut seperti kekerasan emosional atau verbal dan kekerasan fisik. Hasil wawancaradengan anak menunjukkan bahwa sekitar 5 dari 10 siswa mendapatkan dan melakukan tindak kekerasan verbal, seperti mengejek teman dengan sebutan yang jelek, memanggil nama teman dengan sebutan orangtua, berkata kasar saat berberbicara dengan teman menggunakan nama binatang, dan diancam. Sekitar 4 dari 10 anak mengaku pernah mendapatkan dan melakukan kekerasan fisik, kekerasan yang terjadi seperti memukul teman, menendang kaki, dilempar dengan benda keras.

Hasil wawancara dengan salah satu guru di sekolah tersebut mengatakan bahwa perilaku 
kekerasan yang dilakukan oleh siswa tersebut dianggap wajar, karena siswa hanya mengungkapkan apa yang dilihat, dan menirukan perilaku dari teman maupun orang yang tinggal di sekitar mereka, Guru berpendapat bahwa setelah anak tumbuh dewasa maka perilakunya tersebut akan berubah secara perlahan.

Melihat fenomena kekerasan pada anak usia sekolah yang terus meningkat setiap tahunnya, upaya pencegahan dan penatalaksanaan dilakukan untuk menurunkan kejadian ini. Pemerintah Indonesia mengeluarkan undang-undang untuk melindungi anak dari bahaya kekerasan yang tercantum dalam Undang-undang Perlindungan Anak No 23 Tahun 2002, yang meliputi perlindungan kekerasan dalam aspek fisik, emosional, seksual, eksploitasi, penelantaran dan ekonomi. Upaya proteksi ini seharusnya bisa menekan kejadian kekerasan yang timbul di kalangan anak usia sekolah. Namun kenyataannya upaya penanganan ini belum dirasa efektif,dibuktikan kejadian kekerasan pada anak masih terus terjadi dan meningkat setiap tahunnya.

Upaya pencegahan kekerasan juga menjadi tanggung jawab perawat sebagai profesional kesehatan. Perawat perlu mendalami secara luas tentang gambaran fenomena kekerasan pada anak usia sekolah ini sebagai dasar untuk melakukan upaya pencegahan dan penanggulangan kekerasan pada populasi anak usia sekolah. Berdasarkan latar belakang tersebut, dibutuhkan suatu penelitian yang dapat menggambarkan kejadian kekerasan pada anak usia sekolah yang lebih jelas meliputi prevalensi dan gambaran berdasarkan jenis kelamin, usia, latar belakang ekonomi, jenis kekerasan, dan lokasi terjadinya kekerasan. Diharapkan penelitian ini bisa menjadi data dasar sebagai landasan pertimbangan upaya lebih lanjut dalam mengendalikan kekerasan pada anak usia sekolah

\section{METODE}

Penelitian ini menggunakan metode deskriptif kuantitatif, dengan pendekatan cross sectional. Populasi penelitian adalah seluruh siswa di salah satu sekolah dasar di Yogyakarta sebanyak 220 siswa. Teknik pengambilan sampel menggunakan simple random sampling dengan membuat daftar nama kemudian diacak dengan bantuan microsoft excell dan didapatkan hasil sebanyak 130 responden. Adapun kriteria inklusi responden penelitian ini adalah siswa kelas 4 dan 5 yang diizinkan mengikuti penelitian oleh orang tua atau guru, dan tidak terdiagnosa atau memiliki riwayat penyakit jiwa berdasarkan keterangan dari wali kelas masing-masing. Penelitian ini menggunakan siswa kelas 4 dan 5 karena berdasarkan penelitian sebelumnya, kejadian kekerasan banyak terjadi pada tingkatan kelas atas yaitu kelas 4 s.d 6. Peneliti tidak menggunakan sampel kelas 6 karena saat pengambilan data, siswa kelas 6 sedang persiapan ujian akhir nasional sehingga tidak diperkenankan dilibatkan dalam penelitian oleh pihak sekolah.

Instrumen penelitian ini adalah kuesioner gambaran kejadian kekerasan pada anak usia sekolah yang terdiri dari pertanyaan data demografi (usia, jenis kelamin, tingkatan kelas, latar belakang ekonomi), jenis kekerasan, dan lokasi terjadinya kekerasan. Kuesioner ini dikembangkan oleh peneliti berdasarkan penelitian sebelumnya yaitu Latifah (2012) yang dimodifikasi sesuai dengan variabel yang diteliti dan telah dilakukan uji validitas dan reliabilitas pada siswa sekolah dasar yang memiliki karakteristik yang hampir sama dengan sampel berjumlah 30 orang. Kuisioner telah dinyatakan valid dengan nilai $r$ hitung $>0.361$ dan reliabel dengan $r$ sebesar 
0.842. Informed concent diberikan pada orang tua sebelum pelaksanaan pengambilan data. Kuesioner diisi langsung oleh responden dengan didampingi oleh peneliti dan guru. Analisa data menggunakan analisis deskriptif. Penelitian ini telah dinyatakan lolos Uji Etik di Komite Etik dan Penelitian Fakultas Kedokteran dan Ilmu Kesehatan UniversitasMuhammadiyah

Yogyakarta.

\section{HASIL}

\section{Karakteristik Responden}

Berdasarkan Tabel 1, terlihat bahwa responden dalam penelitian ini lebih didominasi anak berusia 11 tahun $(43,8 \%)$, mayoritas berjenis kelamin perempuan $(51,5 \%)$, sebagian besar berasal dari kelas V SD $(56,9 \%)$ dan sebanyak $81(62,3 \%)$ orang tua responden berpenghasilan rendah atau di bawah upah Minimum Kabupaten (UMK) Kabupaten Bantul yaitu kurang dari Rp 1.572.150.

Gambaran Kejadian Kekerasan yang Terjadi pada Anak Usia Sekolah

Berdasarkan Tabel 2, dapat dilihat bahwa gambaran kejadian kekerasan yang terjadi pada anak usia sekolah adalah sebanyak 74 orang $(56,9 \%)$.

\begin{tabular}{lcc}
$\begin{array}{l}\text { Gambaran } \\
\text { berdasarkan }\end{array}$ & $\begin{array}{r}\text { Kejadian } \\
\text { Jenis }\end{array}$ & \multicolumn{2}{c}{$\begin{array}{r}\text { Kekerasan } \\
\text { Kelamin, }\end{array}$} \\
Tingkatan & Kelas, dan Latar \\
Belakang Ekonomi Keluarga &
\end{tabular}

Pada Tabel 3, terlihat bahwa gambaran kejadian kekerasan berdasarkan jenis kelamin lebih sering paada perempuan sebesar 41 siswa $(55,4 \%)$. Kekerasan sebagian besar terjadi pada siswa kelas 5 yakni 41 siswa (55.4\%). Kekerasan lebih banyak terjadi pada siswa dengan keluarga berlatar belakang perekonomian rendah, sebanyak 46 orang $(62,2 \%)$.

\section{Gambaran Kejadian Kekerasan Berdasarkan Jenis-jenis Kekerasan}

Gambaran kejadian kekerasan terbagi dalam 5 jenis kekerasan yaitu kekerasan fisik, seksual, verbal, ekonomi dan pengabaian (Tabel 4). Dari 74 siswa yang mengalami kekerasan, terdapat siswa yang mengalami lebih dari 1 jenis kekerasan. Jenis kekerasan terbanyak pada anak usia sekolah yaitu kekerasan verbal atau emosional $(68,9 \%)$ dan jenis kekerasan yang paling sedikit yaitu jenis kekerasan ekonomi $(36,5 \%)$.

\begin{tabular}{lcc}
\hline \multicolumn{1}{c}{ Karakteristik Responden } & Frekuensi (n) & Persentase(\%) \\
\hline Usia & 27 & \\
10 tahun & 57 & 20,8 \\
1 tahun & 40 & 43,8 \\
12 tahun & 6 & 30,8 \\
13 tahun & $\mathbf{1 3 0}$ & 4,6 \\
\hline Total & & $\mathbf{1 0 0}$ \\
\hline Jenis Kelamin & 63 & 48,5 \\
Laki-laki & 67 & 51,5 \\
Perempuan & 130 & 100 \\
\hline Total & & \\
\hline Kelas & 56 & 43,1 \\
Kelas IV & 74 & 56,9 \\
Kelas V & $\mathbf{1 3 0}$ & $\mathbf{1 0 0}$ \\
\hline Total & & \\
\hline Latar belakang Ekonomi & 81 & 62.3 \\
Pendapatan Keluarga perbulan kategori & & \\
rendah: $<$ Rp 1.572.150 (UMK Bantul) & 49 & 37.7 \\
Pendapatan Keluarga perbulan kategori & & $\mathbf{1 0 0}$ \\
tinggi $\geq$ Rp 1.572.150 (UMK Bantul) & $\mathbf{1 3 0}$ & \\
\hline Total & &
\end{tabular}

Tabel 1. Distribusi frekuensi gambaran karakteristik responden pada anak usia sekolah 


\begin{tabular}{lcc}
\hline Kekerasan & Frekuensi (n) & Persentase (\%) \\
\hline Terjadi & 74 & 56,9 \\
Tidak Terjadi & 56 & 43,1 \\
\hline Total & $\mathbf{1 3 0}$ & $\mathbf{1 0 0}$ \\
\hline
\end{tabular}

Tabel 2. Distribusi frekuensi kejadian kekerasan di anak usia sekolah

\begin{tabular}{lcc}
\hline Variabel & Frekuensi (n) & Persentase (\%) \\
\hline Jenis Kelamin & & \\
\hline $\begin{array}{l}\text { Perempuan } \\
\text { Laki-laki }\end{array}$ & 41 & 55,4 \\
Tingkatan Kelas & 33 & 44,6 \\
\hline Kelas 5 & 41 & 55,4 \\
\hline Kelas 4 & 33 & 44,6 \\
\hline Latar belakang ekonomi & & \\
\hline $\begin{array}{l}\text { Pendapatan Keluarga perbulan } \\
\text { kategori rendah: <Rp 1.572.150 } \\
\text { (UMK Bantul) }\end{array}$ & 46 & 62.2 \\
\hline $\begin{array}{l}\text { Pendapatan Keluarga perbulan } \\
\text { kategori tinggi } \geq \text { Rp 1.572.150 } \\
\text { (UMK Bantul) }\end{array}$ & 28 & 37.8 \\
\hline
\end{tabular}

Tabel 3. Gambaran kejadian kekerasan berdasarkan jenis kelamin, tingkatan kelas, dan pendapatan keluarga perbulan.

\begin{tabular}{lcc}
\hline \multirow{2}{*}{ Jenis Kekerasan } & \multicolumn{2}{c}{ Distribusi Data } \\
\cline { 2 - 3 } Kekerasan Fisik & Frekuensi (n) & Presentase (\%) \\
Terjadi & 41 & 55,4 \\
Tidak terjadi & 33 & 44,6 \\
\hline Total & 74 & 100 \\
\hline Kekerasan Seksual & & \\
Terjadi & 46 & 62,2 \\
Tidak terjadi & 28 & 37,8 \\
\hline Total & 74 & 100 \\
\hline Kekerasan Verbal/Emosional & & \\
Terjadi & 51 & 68,9 \\
Tidak terjadi & 23 & 31,1 \\
\hline Total & 74 & 100 \\
\hline Kekerasan Ekonomi & & \\
Terjadi & 27 & 36,5 \\
Tidak terjadi & 47 & 63,5 \\
\hline Total & 74 & 100 \\
\hline Kekerasan Pengabaian & & \\
Terjadi & 34 & 45,9 \\
Tidak terjadi & 40 & 54,1 \\
Total & 74 & 100 \\
\hline
\end{tabular}

Tabel 4. Distribusi frekuensi jenis kekerasan pada anak usia sekolah.

\section{Gambaran Kejadian Kekerasan Berdasarkan Lokasi Kejadian Kekerasan}

Berdasarkan data pada Tabel 5 di bawah, dapat diamati bahwa kejadian kekerasan berdasarkan lokasi kejadian menunjukkan bahwa lokasi terjadinya kekerasan lebih banyak berada di sekolah $(93,2 \%)$ dan paling sedikit terjadi di rumah 51 (68,9\%). Hasil penelitian ini menunjukkan bahwa satu siswa bisa mengalami kejadian kekerasan lebih dari satu tempat, bisa di sekolah, rumah maupun tempat umum. 


\begin{tabular}{lcc}
\hline \multicolumn{1}{c}{ Lokasi Kekerasan } & Frekuensi (n) & Persentase(\%) \\
\hline Sekolah & 69 & \\
Terjadi & 5 & 93,2 \\
Tidak terjadi & 74 & 6,8 \\
\hline Total & & 100 \\
\hline Rumah & 51 & 68,9 \\
Terjadi & 23 & 31,1 \\
Tidak terjadi & 74 & 100 \\
Total & & \\
Tempat Umum & 59 & 79,7 \\
Terjadi & 15 & 20,3 \\
Tidak terjadi & 74 & 100 \\
\hline Total & 74 & \\
\hline
\end{tabular}

Tabel 5. Gambaran kejadian kekerasan berdasarkan lokasi

\section{PEMBAHASAN}

Hasil

menunjukkan

penelitian ini bahwa kejadian kekerasan pada anak usia sekolah adalah sebanyak 74 kejadian $(56,9 \%)$. Hasil penelitian tersebut menunjukkan bahwa lebih dari separo siswa usia sekolah dasar di Yogyakarta telah mengalami kekerasan. Jumlah kejadian kekerasan pada anak usia sekolah yang terjadi di Yogyakarta ini lebih rendah dibandingkan dengan kejadian kekerasan di Kabupaten Jembrana Bali. Hasil penelitian Dewi (2014) tentang gambaran kejadian dan karakteristik bullying pada anak usia sekolah di sekolah dasar wilayah kerja Puskesmas 1 Pekutatan Kabupaten Jembrana Bali, menyatakan bahwa terdapat kejadian kekerasan pada anak usia sekolah mencapai $71 \%$.

Kekerasan pada anak usia sekolah sering disebut denganViolence Againts Children (VAC). VAC biasanya didefinisikan sebagai pelecehan fisik, seksual, kelalaian yang disebut dengan penganiayaan anak (Wirtz et al, 2016). VAC merupakan suatu pelanggaran hak asasi manusia (HAM) yang terjadi pada anak dan dapat mengakibatkan efek samping seumur hidup bagi anak. Kekerasan yang ada pada anak usia sekolah awalnya dianggap hal yang normal, namun hal ini akan menjadi awal terjadinya pure victim (murni kejadian) atau kejadian kekerasan yang sesungguhnya baik sebagai korban maupun pelaku (Juvonen \& Graham, 2014).

Berdasarkan hasil penelitian ini, terdapat lima jenis kekerasan yang terjadi pada anak usia sekolah yaitu kekerasan fisik, verbal atau emosional, seksual, ekonomi dan pengabaian. Setiap responden bisa mengalami lebih dari 1 jenis kekerasan dalam 1 bulan terakhir,

Berdasarkan jenis kekerasan yang terjadi pada anak usia sekolah dalam penelitian ini menunjukkanbahwa terdapat 41 anak $(55,4 \%)$ mengalami atau melakukan tindak kekerasan fisik. Bentuk-bentuk kekerasan fisik diantaranya adalah dipukul, dicubit, didorong hingga hampir terjatuh oleh teman, dsb (Hurairah, 2012). Berdasarkan hasil analisis item kuesioner penelitian ini tentang kekerasan fisik menunjukkan bahwa jenis kekerasan fisik pada anak usia sekolah lebih didominasi dalam bentuk dipukul oleh orang lain dan dicubit. Hasil penelitian UNICEF dalam Radja, et.al (2016) menunjukkan bahwa terdapat 93\% perempuan dan $87 \%$ laki-laki menganggap bahwa kekerasan fisik seperti memukul atau dipukul itu hal yang normal dan banyak terjadi. Kekerasan fisik dianggap dapat menjadi hukuman fisik (corporal punishment) kepada anak jika melakukan kesalahan di rumah. Namun jika kekerasan fisik ini dibiarkan, akan menyebabkan luka 
yang serius seperti luka lebam, berdarah bahkan korban bisa sampai meninggal dunia (Muthmainnah, 2014)

Selain kekerasan fisik, responden pada penelitian ini juga terlibat dalam kejadian kekerasan seksual. Sebanyak $62,2 \%$ siswa terlibat dalam kekerasan seksual. Berdasarkan hasil analisis item kuesioner tentang kekerasan seksual pada anak usia sekolah, menunjukkan bahwa kekerasan seksual sebagian besar dalam bentuk anak melihat lawan jenis saat berganti pakaian. Kejadian seperti ini bukan merupakan hal yang wajar, karena akan berisiko munculnya kejadian kekerasan seksual yang lebih parah seperti pelecehan organ reproduksi, bahkan sampai dengan pencabulan atau persetubuhan secara paksa. Hasil penelitian ini didukung dengan penelitian Gani (2016) yang menyatakan bahwa terdapat kejadian kekerasan seksual pada anak sebesar 62,2\%. Kekerasan seksual yang sering terjadi pada anak yaitu seperti melihat gambar yang tidak pantas dilihat atau melihat saat lawan jenis berganti pakaian serta memegang pantat teman atau teman lawan jenis. Menurut Komisi perlindungan anak nasional Tahun 2015 bahwa 9\% anak pernah menjadi korban perlakuan tindak senonoh dari orang lain, 97\% anak pernah menonton video porno, ucapan yang tidak senonoh dan tindakan pelecehan organ reproduksi anak. Tahun 2010 sebanyak 15,52\% anak pernah mengalami pencabulan atau persetubuhan secara paksa yang dilakukan oleh orang lain dan kejadian ini mengalami peningkatan pada tahun 2013 sebanyak 22,77\% (Kemenkes, 2014).

Kekerasan seksual yang terjadi pada anak usia sekolah bisa dipengaruhi oleh beberapa faktor, salah satunya yaitu komunikasi antar anggota keluarga. Komunikasi yang baik antara keluarga dan anak, akan menurunkan risiko terjadinya kekerasan seksual pada anak. Anak yang mendapatkan pendidikan dini terkait seksual dari orang tua melalui komunikasi yang baik, dapat mencegah timbulnya tindakan kekerasan seksual (Handayani, 2017).

Jenis kekerasan lainnya adalah kekerasan verbal atau emosional. Kekerasan verbal merupakan jenis kekerasan terbanyak yang terjadi pada anak usia sekolah yaitu sebesar 51 kejadian $(68,9 \%)$. Hasil penelitian ini sejalan dengan penelitian Hayati (2013), yang menjelaskan bahwa kekerasan verbal merupakan jenis kekerasan yang paling dominan pada anak usia sekolah. Kejadian kekerasan ini paling banyak terjadi dalam bentuk ejekan, ancaman, dan pengucilan teman. Berdasarkan hasil analisa item kuesioner mengenai kekerasan verbal/emosional bahwa kekerasan yang sering dilakukan atau diterima oleh anak usia sekolah yaitu mengejek karena bodoh atau mengganti nama teman dengan sebutan jelek. Radja et al (2016) menjelaskan bahwa hampir sebagian anak menganggap bahwa ejekan atau kata yang kasar bukan merupakan tindak kekerasan, anak menganggap bahwa suatu ejekan merupakan hal biasa dan hanya sebuah gurauan yang tidak akan berdampak apapun. Hal ini perlu mendapat perhatian karena kekerasan verbal atau emosional pada anak usia sekolah memiliki dampak yang signifikan bagi kondisi psikologis korban seperti perasaan minder, merasa tidak berharga, sulit membina hubungan, dan menarik diri dari pergaulan (Muthmainnah, 2014)

Selain kekerasan verbal, jenis kekerasan yang lainnya adalah kekerasan ekonomi. Hasil penelitian menunjukkan bahwa prevalensi kekerasan ekonomi pada responden lebih rendah dibandingkan jenis kekerasan yang lain yaitu sebesar $36,5 \%$. Kejadian kekerasan ekonomi pada anak usia sekolah dikuatkan oleh penelitian Rahmawati dan Siregar (2012) bahwa terdapat 1 dari 
3 partisipan penelitiannya yang mendapatkan kekerasan ekonomi. Terdapat $22 \%$ anak mengalami eksploitasi dan dipekerjakan secara berlebihan (Komnas HAM, 2015) Faktor yang dapat mempengaruhi terjadinya kekerasan ekonomi yaitu faktor latar belakang ekonomi keluarga. Ekonomi yang rendah dapat menyebabkan orangtua mudah sekali meluapkan emosi kepada orang sekitar. Anak dapat menjadi sasaran luapan emosi karena anak sebagai makhluk yang lemah dan rentan (Fitriana, Pratiwi \& Sutanto, 2015).

Berdasarkan hasil penelitian diperoleh bahwa jumlah kekerasan pengabaian sekitar 45,9\%. Tindakan pengabaian atau penelantaran adalah ketidakadilan orangtua atau yang bertanggungjawab atas anak, seperti tidak terpenuhinya kesehatan anak, pendidikan, gizi, dan perkembangan emosi (terlalu dikekang), pengabaian dan penelantaran pada penyediaan rumah, pengabaian pada kondisi keamanan dan kenyamanan (P2TP2A, 2011). Berdasar data yang dihimpun selama 3 tahun oleh Komisi Nasional Hak Asasi Manusia Republik Indonesia (2015), terdapat kasus anak terlantar sebanyak 4,8 juta anak. Terjadinya pengabaian pada anak bisa disebabkan karena faktor kematangan fisik, emosi dan sosial orang tua. Orang tua yang memiliki kematangan dalam aspek tersebut akan lebih siap untuk membesarkan anak, memenuhi kebutuhannya sehingga mengurangi risiko terjadinya kekerasan (Hurairah, 2012)

$$
\text { Hasil penelitian mengenai }
$$

gambaran kejadian kekerasan pada anak usia sekolah berdasarkan jenis kelamin menunjukkan bahwa kejadian kekerasan lebih dari setengahnya dilakukan oleh responden perempuan $(55,4 \%)$. Hasil tersebut sejalan dengan penelitian Radja, et.al (2016) menyatakan bahwa kekerasan yang terjadi didominasi oleh responden dengan jenis kelamin perempuan sebesar $(53,8 \%)$.
Menurut Abdullah (2013), kekerasan yang sering dilakukan oleh anak perempuan yaitu kekerasan verbal maupun non-verbal. Bentuk kekerasan verbal seperti mengejek, menertawakan korban, mengganti nama korban dengan sebutan jelek/orangtua, dan mengancam, sedangkan bentuk kekerasan nonverbal seperti mengasingkan korban, memalingkan muka terhadap korban. Kekerasan yang dilakukan pada anak laki-laki cenderung bersifat kontak fisik atau menggunakan kekuatan fisik seperti memukul, mendorong korban dan menjahili korban, karena anak laki-laki lebih banyak menggunakan kekuatan tubuh dibandingkan perempuan.

Hasil studi mengenai gambaran kejadian kekerasan berdasarkan tingkatan kelas, didominasi dengan tingkatan kelas lima 31 orang $(55,4 \%)$ dan diikuti kelas empat (44,6\%). Hasil ini sesuai dengan Rohman (2016), yang menyatakan bahwa kejadian kekerasan sebagai korban bullying lebih banyak terjadi pada tingkatan kelas atas atau yang lebih tinggi. Faktor risiko terjadinya kekerasan pada tingkatan tersebut karena adanya minat terhadap kehidupan secara praktis dan memiliki rasa ingin tahu terhadap dunia luar (Rohman, 2016).

Deskripsi kekerasan selain berdasarkan tingkatan kelas berdasarkan juga latar belakang dari perekonomiankeluarga. Hasil ini menunjukkan bahwa sebagian besar responden berlatar belakang ekonomi di bawah UMK Bantul atau penghasilan kurang dari Rp 1.572.150. Ini sejalan dengan penelitian Verawati dan Ernawati (2014), menyatakan bahwa tingkat pendapatan keluarga perbulan berada di bawah UMK sebanyak 22 orang (53,7\%).

Latar belakang ekonomi yang rendah dapat menjadi alasan untuk orang tua mempunyai temperamen yang mudah marah, karena orangtua 
lebih memprioritaskan untuk memenuhi kebutuhan keluarga, memiliki tekanan terhadap kelanjutan hidup dari keluarga, dan lebih mementingkan untuk mencari tambahan penghasilan dibandingkan untuk merawat anak. Faktor latar belakang ekonomi yang rendah juga dapat menyebabkan orangtua kelelahan dan kesabaran dalam mengasuh anak akan berkurang. Selain itu orang tua juga bisa mengabaikan atau tidak mempedulikan anak-anak di rumah, karena kesibukan setiap hari sehingga peran orang tua di rumah untuk merawat anak terabaikan (Fatimawati \& Anggraeni, 2014).

Deskripsi kekerasan selanjutnya adalah berdasarkan lokasi terjadinya kekerasan. Kekerasan yang terjadi di anak usia sekolah dalam penelitian ini lebih didominasi terjadi di sekolah sebesar 69 (93,2\%). Sejalan dengan penelitian Dewi (2014) yang menyebutkan bahwa lokasi kejadian kekerasan paling banyak dilakukan sekolah dan terjadi di luar kelas $(77,1 \%)$. Hal tersebut dipengaruhi oleh tidak adanya pengawasan oleh guru saat berada di luar kelas. Hal tersebut dapat terjadi karena beberapa faktor yang mempengaruhi seperti faktor peraturan sekolah. Kekerasan di sekolah juga bisa disebabkan oleh kontrol sosial (peer group). Pelaku kekerasan menjadi lebih kuat jika di sekeliling anak terdapat orang yang membantu. Jadi ketika anak berada dalam kelompok sebaya yangmendukung terjadinya kekerasan, maka anak cenderung akan melakukan kekerasan tersebut (Dewi, 2014).

\section{KESIMPULAN}

Berdasarkan hasil penelitian dapat disimpulkan bahwa lebih dari separuh anak usia sekolah terlibat dalam kekerasan. Jenis kekerasan yang paling banyak terjadi yaitu jenis kekerasan verbal. Kekerasan pada anak lebih banyak terjadi di sekolah.
Penelitian ini diharapkan dapat menjadi rekomendasi sekolah untuk mengambil kebijakan terhadap kejadian kekerasan pada anak usia sekolah. Selain ini, dapat juga dijadikan sebagai data dasar penelitian selanjutnya mengenai faktor-faktor yang dapat memicu terjadinya kekerasan pada anak. Bagi pelayanan keperawatan, hasil penelitian ini diharapkan menjadi data untuk melakukan upaya promotif dan preventif pada anak usia sekolah. Bagi siswa, hasil ini dapat memberikan pengetahuan mengenai gambaran kejadian yang terjadi di sekitar lingkungan siswasehingga dapat melakukan upaya pencegahan dari diri sendiri. Implikasi penelitian ini bagi orang tua adalah untuk mencegah kekerasan pada anak, orang tua diharapkan dapat menciptakan situasi atau lingkungan keluarga yang penuh kasih sayang dalam menerapkan norma keluarga tanpa adanya kekerasan.

\section{DAFTAR PUSTAKA}

Abdullah, N. (2013). Meminimalisasi Bullying di Sekolah. Magistra, 25(83), 50-55.

Beattie, R. (2015). Long-term Effect of Bullying. Archieve of Disease in Childhood, 100(9i). DOI: 10.1136/archdischild-2015-309491.

Dewi, D. A. (2014). Gambaran Kejadian dan Karakteristik Bullying pada Anak Usia Sekolah di Sekolah Dasar Wilayah Kerja Puskesmas 1 Pekutatan Kabupaten Jembrana Bali. ISM, 8(1), 1-9.

Erlinda. (2014). Upaya Peningkatan Anak dari Bahaya Kekerasan, Pelecehan dan Eksploitasi.https://web.kominfo.go.id/

Fatimawati, I., \& Anggraeni, S. P. (2014). Hubunan Status Ekonomi Keluarga Dengan Kejadian Kekerasan Pada Anak (Chld Abuse) Di Komunitas Anak Jalanan Kota Mojokerto. Medica Majapahit, 6(2), 1-11.

Fitriana, Y., Pratiwi, K. \& Sutanto, A.V, (2015). Faktor-faktor yang berhubungan dengan perilaku orang tua dalam melakukan kekerasan verbal terhadap anak usia prasekolah. Jurnal psikologi Universitas Diponegoro Vol 14, No 1: April 2015.

Gani, H. A. (2016). Kekerasan terhadap Anak : Tinjauan dari Sisi Pelaku (Studi di Wilayah Kabupaten Jember). Jurnal pemikiran dan penelitian psikologi $\mathrm{Vol}$ 12, No 12016 
Handayani, M. (2017). Pencegahan Kasus Kekerasan Seksual Pada Anak Melalui Komunikasi Antarpribadi Orangtua dan Anak. Jurnal Ilmiah Visi PGTK PAUD dan DIKMAS, 2(1),67-80.

Hayati, S. (2013). Gambaran Kekerasan yang Dilakukan Orang Dewasa pada Anak Jalanan di Kota Bandung. Jurnal Ilmu Keperawatan, 1(1), 14-18.

Hillis, S., Mercy, J., Amobi, A., \& Kress, H. (2017). Global Pravelence of Past-year Violence Against Children: A Systematic Review and Minimum Estimetas. Pediatrics, 137(3), 1-13.

Hurairah, A. (2012). Kekerasan terhadap Anak. Bandung: Nuansa Cendekia.

Juvonen, J., \& Graham, S. (2014). Bullying in School: The Power of Bullies and the Plight of Victims. Annual Review of Psychology, 65(1), 159-185.

Kementerian Kesehatan Republik Indonesia. (2014). Tingkatkan Kerjasama dan Kewaspadaan Kekerasan pada Anak.https://www.kemkes.go.id/

Kementerian Pemberdayaan Perempuan dan Perlindungan Anak Republik Indonesia. (2011). Peraturan Menteri Negara Pemberdayaan Perempuan dan Perlindungan Anak Republik Indonesia Nomor 2 Tahun 2011 Tentang Pedoman Penanganan Anak Korban Kekerasan. Jakarta: Kementerian Pemberdayaan Perempuan dan Perlindungan Anak Republik Indonesia. http://ditjenpp.kemenkumham.go.id

Komisi Nasional Hak Asasi Manusia Republik Indonesia (2015). Laporan Tahunan Komnas HAM 2015. www.komnasham.go.id

Latifah, F. (2012). Hubungan Karakterisrik Anak Usia Sekolah dengan Kejadian Bullying Di Sekolah Dasar X di Bogor. Skripsi: Universitas Indonesia

Morcillo, C., Ramos-Olazagasti, M., C, B., Salsa, R., Canino, G., Bird, H., \&\& DUarte, C. S. (2015). Socio-Cultural Context and Bullying Others in Childhood. Journal of Child and Family Studies, 24(8). DOI: 10.1007/s10826014-0026-1, 2241-2249.

Muthmainnah. (2014). Membekali Anak dengan Ketrampilan Melindungi Diri. Jurnal Pendidikan Anak Vol 3. No 12014

Pemerintah Indonesia. (2002). Undang-undang No 23 Tahun 2002 Tentang Perlindungan Anak. Jakarta:
Pemerintah

https://www.ilo.org/

Pusat Pelayanan Terpadu Pemberdayaan Perempuan dan Anak (P2TP2A). (2011). Data Pusat Pelayanan Terpadu Pemberdayaan Perempuan dan Anak. Kementerian Pemberdayaan Perempuan dan Perlindungan Anak Republik Indonesia.

Radja, R. D., Kaunang, T. M., Dundu, A. E., \& Munayang, H. (2016). Gambaran Kekerasan pada Anak Sekolah Dasar di Kecamatan Malalayang Kota Manado. Jurnal e.Clinic, 4(2), 1-6.

Rahmawati, N., \& Siregar, M. A. (2012). Gambaran Resiliensi Pada Pekerja Anak Yang Mengalami Abuse. Predicara, Volume. 1 Nomor. 2.

Rohman, M. Z. (2016). Hubungan Antara Usia, Tingkatan Kelas, Dan Jenis Kelamin Dengan Kecenderungan Menjadi Korban Bullying.https: / / publikasiilmiah.ums.ac .id

Silvia, M.A.,Pereira, B., Mendonca, D.,Nunes, B.\& Oliveira, W.A. (2013). The Involvement of Girls and Boys with Bullying: an Analysis of Gender Differences. International Journal of Environmental Research and Public Health ISSN 16604601www.mdpi.com/journal/ijerph, 10, 6820-6831

Suradi. (2013). Problema dan Solusi Strategis Kekerasan terhadap Anak.Informasi, 18(02), 183-202.

Verawati, M., \& Ernawati, H. (2014). Analisa Persepsi Orangtua Tentang Kekerasan Pada Anak Di Ponorogo. Jurnal Kebidanan dan Keperawatan, 10(2), 186-192.

Wirtz, A. L., Alvarez, C., Guedes, A. C., Brumana, L., Modvar, C., \& Glass, N. (2016). Violence against children in Latin America and Caribbean countries : a comprehensive review of national health sector efforts in prevention and response. BMC Public Health, 16(1), 1006-1022.

Zwierzynska, K., Wolke, D., \& Lereya, \&. T. (2013). Peer Victimization in Chilhood and Internalizing Problems in Adolencence: Prospective Longitudinal Study. Journal of Abnormal Child Psychology, 41(2), 309-323. DOI: $10.1007 / \mathrm{s} 10802-012-9678$ - 